\title{
Minat Karyawan Dalam Pembiayaan Kepemilikan Kendaraan Bermotor Melalui Produk
}

\section{Amanah}

\author{
Oleh: Nur Muhammad Lakdar Baluntu
}

\begin{abstract}
ABSTRAK
Penelitian ini untuk mengetahui minat karyawan dalam pembiayaan, dan apakah proses penerapannya telah sesuai dengan konsep ekonomi Islam. Jenis penelitian ini adalah penelitian lapangan yang bersifat deskriptif kualitatif studi kasus. Maka penelitian ini dimaksudkan untuk menggambarkan, mendepenelitiankan atau melukiskan suatu keadaan, gejala atau kelompok tertentu secara terperinci. Dalam hal ini penelitian dimaksudkan untuk mendepenelitiankan bagaimana proses pembiayaan kendaraan bermotor. Sedangkan penelitian ini bersifat studi kasus, dalam hal ini ditujukan pada Cabang Pegadaian Syariah Istiqlal Manado.

Adapun tujuan penelitian ini adalah untuk mengetahui sistem pembiayaan di Pegadaian Syariah, dan untuk menganalisa dari sudut pandang hukum ekonomi Islam tentang produk amanah di Cabang Pegadaian Syariah Istiqlal Manado. Kemudian yang berkaitan dengan kegunaan penelitian ini yakni bermanfaat untuk menambah wawasan dan pengetahuan dan dipergunakan sebagai pertimbangan dan acuan bagi kalangan umat Islam dalam praktek pembiayaan kendaraan bermotor, lebih khusus lagi Cabang Pegadaian Syariah Manado dan nasabah yang menjadi objek penelitian tersebut. Selain itu, dengan penelitian ini secara tidak langsung menjadikan sebagai wahana sosialisasi tentang ekonomi Islam. Dalam aspek keilmuan, dan penelitian ini dapat memperkaya pengetahuan di bidang fiqih muamalah, khususnya dalam hal pembiayaan yang diajarkan oleh hukum Islam.

Dari hasil penelitian mengenai mengenai produk Amanah di Pegadaian Syariah sudah sesuai dengan konsep ekonomi Islam karena penerapan pelaksanaan pembiayaan Amanah yang dilakukan oleh Pegadaian Syariah Istiqlal Manado di lihat dari rukun dan syarat sudah sesuai dengan konsep ekonomi Islam, yaitu ada pihak yang bertransaksi, objek perjanjian, persyaratan sederhana, prosedur mudah, akad secara tertulis, dan isi perjanjian ditentukan oleh kedua belah pihak serta tidak mengandung gharar, sampai berakhirnya perjanjian dilakukan berdasarkan kesepakatan antara kedua belah pihak yaitu nasabah dan pihak Pegadaian, dann juga perjanjian yang dilakukan antara kedua belah pihak dilandasi dengan ikatan hukum yang kuat.
\end{abstract}




\section{PENDAHULUAN}

\section{A. Latar Belakang Masalah}

Produk-produk berbasis syariah memiliki karakteristik seperti tidak memungut bunga dalam berbagai bentuk karena riba. ${ }^{1}$ Menetapkan uang sebagai alat tukar bukan sebagai komuditas yang diperdagangkan. Dengan begitu banyak produk yang ditawarkan pegadaian syariah maka produktivitas perlu ditingkatkan karena merupakan faktor terpenting dalam suatu usaha yang dijalankan agar tetap dapat tumbuh dan berkembang, serta menentukan daya saing di era pasar bebas yang akan datang. Potensi untuk berkembang lebih maju di masa mendatang masih sangat besar. Namun masih ada banyak kendala dan tantangan dalam operasional pegadaian Syariah di Indonesia.

Produk Pegadaian Syariah yang ditawarkan pada umumnya meliputi: ${ }^{2}$

1. Penyaluran pinjaman secara gadai yang didasarkan pada penerapan prinsip Syariah Islam dalam transaksi ekonomi secara syariah (gadai emas biasa).

2. Pembiayaan ARRUM (Ar Rahn Untuk Usaha Mikro/Kecil), yaitu pembiayaan yang dikhususkan untuk UMM (Usaha Kecil Mikro Menengah) dengan obyek jaminan berupa BPKB (Bukti Permilikan Kendaraan Bermotor).

3. Pembiayaan MULIA (Murabahah Logam Mulia Untuk Investasi Abadi), yaitu penjualan logam mulia oleh Pegadaian kepada masyarakat secara tunai atau angsuran, dan agunan jangka waktu fleksibel.

4. Amanah, yaitu pembiayaan kepemilikan kendaraan bermotor bagi karyawan

Kegiatan pembiayaan yang diberikan oleh Pegadaian Syariah sebagai murtahin kepada nasabahnya sebagai rohin diikat dengan berbagai akad yang sah sesuai dengan prinsip-prinsip ekonomi syariah. Akad secara etimologis berarti ikatan antara dua perkara, baik ikatan secara nyata maupun secara maknawi, dari satu segi maupun dari dua segi. ${ }^{3}$ Secara istilah, akad adalah

${ }^{1}$ Riba berasal dari bahasa Arab, secara etimologis berarti tambahan (azziyadah), Menurut terminologi ilmu fiqh, riba merupakan tambahan khusus yang dimiliki salah satu pihak yang terlibat tanpa adanya imbalan tertentu. Riba sering juga diterjemahkan dalam bahasa Inggris sebagai "usury" dengan arti tambahan uang atas modal yang diperoleh dengan cara yang dilarang oleh syara', baik dengan jumlah tambahan yang sedikit atau pun dengan jumlah tambahan banyak. Dikutip dari Abu Sura'i Abdul Hadi, Bunga Bank Dalam Islam, alih bahasa M. Thalib (Surabaya: al-Ikhlas, 1993), h.125

${ }^{2}$ Sumber data dikutip dari dokumen atau brosur-brosur Pegadaian Syariah Istiqlal Manado
${ }^{3}$ Rahmat Syafei, Fiqh Muamalah untuk UIN, STAIN, PTAIS dan Umum (Bandung: Pustaka Setia, 2006), h. 
perikatan yang ditetapkan dengan ijab kabul berdasarkan ketentuan syara' yang berdampak pada obyeknya. ${ }^{4}$ Akad juga merupakan salah satu cara untuk memperoleh harta dalam hukum Islam dan dipakai dalam kehidupan sehari-hari. ${ }^{5}$

Produk ini merupakan produk baru dalam Pegadaian Syariah. Produk ini akan sangat membantu nasabah yang ingin memiliki kendaraan bermotor, baik motor maupum mobil. Tapi produk ini hanya dibataskan kepada karyawan saja. Namun seiring dengan perkembangannya produk Amanah ini ditawarkan di berbagai lembaga-lembaga keuangan lainya. Hal ini tentu saja menjadi tantangan dan masalah bagi bank syariah, terutama dalam hal peningkatan pendapatan.

Untuk mengetahui yang sebenarnya bagaimana praktik akad murabahah yang terjadi dalam transaksi ini, dan juga mengetahui apakah sistem pembiayaan yang ada tidak terdapat unsur yang bertentangan dengan ekonomi Islam maka penulis menilai bahwa penting untuk mengadakan penelitian dan membahas masalah tersebut.

Oleh karena itu penulis tertarik untuk menulis penelitian ini dengan judul: Minat Karyawan Dalam Pembiayaan Kepemilikan Kendaraan Bermotor Melaui Produk Amanah.

\section{B. Rumusan Dan Batasan Masalah}

Berdasarkan latar belakang masalah di atas maka penulis hanya membatasi masalah yang akan dibahas dalam karya tulis ini. Adapun rumusan dan batasan masalah adalah sebagai berikut:

1. Bagaimana minat karyawan dalam pembiayaan produk Amanah di Pegadaian?

2. Bagaimana pandangan ekonomi Islam terhadap produk Amanah di Pegadaian Syariah Manado?

\section{LANDASAN TEORI}

\section{A. Pengertian Produk Amanah}

Produk Pegadaian Amanah dapat didefinisikan sebagai suatu skim pemberian pinjaman kepada masyarakat yang berpenghasilan tetap guna kepemilikan kendaraan bermotor. Pemberian pinjaman ini diberikan dalam jangka waktu tertentu yang pengembaliannya dilakukan secara

\footnotetext{
${ }^{4}$ Ibid, h. 44

${ }^{5}$ Gemala Dewi, Aspek-aspek Hukum dalam Perbankan dan Perasuransian Syariah di Indonesia, Edisi Revisi (Jakarta: Kencana Prenada Media Group, 2006), h. 11
} 
angsuran. Perikatan jaminan dilakukan secara fidusia atas obyek produk Pegadaian Amanah tersebut. $^{6}$

\section{B. Prosedur dan Persyaratan Nasabah}

Adapun Prosedur dan syarat yang berlaku adalah sebagai berikut:

\section{Prosedur}

a) Calon nasabah mengajukan kredit melalui bendaharawan gaji pada instansi/perusahaan tempat bekerja.

b) Mengisi formulir yang telah disediakan dengan menyerahkan persyaratan yang ditentukan.

c) Pembiayaan mulai Rp 5.000.000 hingga Rp 150.000.000

d) Jangka waktu kredit 12 bulan, 24 bulan, dan 36 bulan.

\section{Persyaratan}

a) Pegawai tetap dalam suatu instansi/perusahaan dengan masa kerja minimal 2 tahun.

b) Mempunyai tempat tinggal tetap.

c) Jarak tempat tinggal calon nasabah dengan Pegadaian maksimal $25 \mathrm{~km}$.

d) Sanggup membayar uang muka yang besarnya ditetapkan berdasarkan jangka waktu kredit dan biaya administrasi.

\section{Sistem Pembiayaan dari produk Amanah}

\section{A. Persyaratan menjadi nasabah di Pegadaian}

Produk Amanah merupakan produk pembiayaan yang ada di cabang Pegadaian syariah istiqlal yang dimana inti dari produk Amanah ini adalah memberikan pinjaman guna kepemilikan kendaraan bermotor kepada para pegawai tetap pada instansi atau perusahaan tertentu atas dasar besarnya penghasilan (gaji) dalam jangka waktu tertentu dengan pengembalian dilakukan secara angsuran. Adapun syarat-syarat untuk menjadi nasabah di produk Amanah yaitu: ${ }^{7}$

1. pegawai tetap dalam suatu instansi dengan masa kerja minimal 2 tahun dan khusus untuk Pegadaian minimal 1 tahun

\footnotetext{
${ }^{6}$ Pedoman Operasional PEGADAIAN AMANAH untuk Pembiayaan kendaraan Bermotor, Divisi Litbang dan Pemasaran Perum Pegadaian, h. 3.

${ }^{7}$ Wawancara dengan Mochtar Kadi. Amd. Ak selaku Analis dan dokumen dari kantor Cabang Pegadaian Syariah Istiqlal Manado, Tanggal 6 November 2013.
} 
2. minimal usia 21 tahun

3. kendaraan dipakai oleh diri sendiri (pemohon) kendaraan digunakan diwilayah pemohon (tidak digunakan di luar wilayah, misalnya pemohon tinggal di Manado sedangkan kendaraan di Gorontalo)

4. pada dasarnya instansi dapat diberikan pinjaman Amanah namun khusus pada pegawai instansi berikut, pemberian Amanah harus lebih selektif dan cermat mengingat turn over (mutasi yang cukup tinggi) seperti pegawai anggota kepolisian, anggota TNI, anggota lembaga yudikatif dan anggota lembaga legislatif.

5. melampirkan kelengkapan administrasi yaitu:

a. foto copy KTP (suami/istri jika telah berkeluarga), jika alamat tempat tinggal berbeda dengan KTP maka harus menyertakan surat keterangan domisili dari kelurahan/desa.

b. foto copy kartu keluarga (KK), bila pasangan suami istri belum mempunyai kartu keluarga, boleh menggunakan KK induk.

c. foto copy surat nikah.

d. foto copy kartu tanda pengenal di perusahaan yang bersangkutan dan kartu anggota bagi TNI/POLRI.

e. foto copy surat keputusan pengangkatann sebagai pegawai tetap

f. asli daftar slip gaji selama 2 bulan terakhir yang disahkan pejabat berwenang

g. surat persetujuan suami istri

h. mengisi dan menandatangani form aplikasi Amanah. ${ }^{8}$

Persyaratannya yaitu Pegawai tetap dalam suatu instansi/perusahaan dengan masa kerja minimal 2 tahun, mempunyai tempat tinggal tetap, Jarak tempat tinggal calon nasabah dengan Pegadaian maksimal $25 \mathrm{~km}$, sanggup membayar uang muka yang besarnya ditetapkan berdasarkan jangka waktu kredit dan biaya administrasi. ${ }^{9}$

Dari data di atas penulis dapat menyimpulkan ternyata persyaratan dari produk Amanah di Pegadaian Syariah sudah sesuai dengan konsep Islam karena sebelum menjadi nasabah harus ada persyaratan yang diikuti oleh calaon nasabah sebelum menjadi nasabah produk Amanah. Hal

\footnotetext{
${ }^{8}$ Wawancara dengan Mochtar Kadi. Amd. Ak selaku Analis dan dokumen dari kantor Cabang Pegadaian Syariah Istiqlal Manado, Tanggal 6 November 2013.

${ }^{9}$ Syamsul Anwar, Hukum Perjanjian syariah Studi tentang Teori Akad dalam Fikih Muamalat (Jakarta: PT. Raja Grafindo Persada, 2007), h. 89.
} 
yang menjadi persyaratan antara lain: menyerahkan identitas lengkap berupa alamat yang sebenarnya dan menyerahkan KTP dan foto copy kartu keluarga (KK), bila pasangan suami istri belum mempunyai kartu keluarga, boleh menggunakan KK induk, foto copy surat nikah, foto copy kartu tanda pengenal di perusahaan yang bersangkutan dan kartu anggota bagi TNI/POLRI, foto copy surat keputusan pengangkatann sebagai pegawai tetap, asli daftar slip gaji selama 2 bulan terakhir yang disahkan pejabat berwenang, surat persetujuan suami istri, mengisi dan menandatangani form aplikasi Amanah.

\section{B. Perjanjian antara nasabah dan Pegadaian}

Mengenai perjanjian yang terjadi antara pihak nasabah dengan Pegadaian mengenai produk Amanah ini yaitu:

1. rahin menyerahkan bukti kepemilikan barang kepada murtahin

2. penyimpanan barang jaminan dalam bentuk bukti kepemilikan yang sah atau sertifikat tersebut tidak memindahkan kepemilikan barang dari rahin ke murtahin.

3. pemanfaatan barang marhun oleh rahin harus dalam batas kewajaran sesuai kesepakatan

4. rahin memberikan wewenang kepada murtahin untuk mengeksekusi barang tersebut apabila terjadi wanprestasi atau tidak dapat melunasi utangnya.

5. apabila terjadi wanprestasi atau rahin tidak dapat melunasi utangnya, maka murtahin dapat menjual marhun secara paksa (eksekusi langsung), baik melalui lelang atau dijual ke pihak lain sesuai prinsip syariah.

6. murtahin dapat mengenakan biaya kepada rahin atas pemeliharaan dan penyimpanan barang marhun (berupa bukti kepenilikan sah atau sertifikat).

7. besaran biaya pemeliharaan dan penyimpanan barang marhun tersebut tidak boleh dikaitkan dengan jumlah pinjaman yang diberikan.

8. besaran biaya sebagaimana dimaksud huruf (g) tersebut didasarkan pada pengeluaran yang riil.

9. biaya asuransi atas marhun ditanggung oleh rahin. 
Jika salah satu pihak tidak menunaikan kewajibannya atau jika terjadi perselisihan diantara para pihak, maka penyelesainnya dilakukan melalui Badan Arbitrase Syariah atau Pengadilan Agama setelah tidak tercapai kesepakatan melalui musyawarah. ${ }^{10}$

Dari penjelasan di atas mengenai perjanjian antara nasabah dan pihak Pegadaian itu memuat tentang bagaiamana hak dan kewajiban antara kedua pihak, penulis dapat menyimpulkan ternyata untuk hak dan kewajiban antara nasabah dan pihak pengadaian ternyata tidak terlalu menyulitkan nasabah karena hanya memasukan beberapa surat-surat atau dokumen seperti surat bukti kepemilikan barang kepada murtahin, penyimpanan barang jaminan dalam bentuk bukti kepemilikan yang sah atau sertifikat tersebut tidak memindahkan kepemilikan barang dari rahin ke murtahin, rahin memberikan wewenang kepada murtahin untuk mengeksekusi barang tersebut apabila terjadi wanprestasi atau tidak dapat melunasi utangnya.

\section{Objek dan standarisasi dalam pembiayaan Amanah}

Objek yang ada dalam pembiayaan Amanah yang ada di Pegadaian kami adalah kendaraan bermotor, yang dimaksud kendaraan bermotor dibatasi pada kenndaraan sepeda motor dan mobil. Adapun standarisasi pembiayaan dalam Amanah adalah sebagai berikut:

1. Batas minimum nilai pinjaman pegadaian amanah ditetapkan sebesar Rp. 5.000.000,(lima juta rupiah) dan batas maksimum sebesar Rp. 150.000.000,- (seratus lima puluh juta rupiah) dengan kelipatan Rp. 500.000,- (lima ratus ribu rupiah).

2. Menetapkan metode perhitungan penetapan besarnya nilai pinjaman Pegadaian Amanah berdasarkan dua pendekatan (rumusa) dan dipilih yang terkecil hasilnya dari dua pendekatan tersebut.

Kedua pendekatan (rumus) tersebut di atas meliputi:

a. Berdasarkan repayment capacity yang berumber dari penghasilan bersih

Marhun Bih $=1 / 3 \times$ penghasilan bersih $\mathrm{x}$ jangka waktu pinjaman (bulan)

\footnotetext{
${ }^{10}$ Wawancara dengan Wagiman. SE selaku pimpinan Cabang Pegadaian Syariah tanggal 6 November 2013.
} 
b. Berdasarkan nilai taksiran kendaraan

1) Jika digunakan untuk pembelian kendaraan sepeda motor dan mobil yang digunakan untuk tujuan produktif.

$$
\text { Marhun Bih }=\text { taksiran kendaraan } \times 10 \%
$$

2) Jika digunakan untuk pembelian mobil yang digunakan untuk tujuan nonproduktif.

$$
\text { Marhun Bih = taksiran kendaraan x 75\% }
$$

3. Pinjaman di atas Rp. 50.000.000,- (lima puluh juta rupiah) dilengkapi dengan Nomor atau kopi NPWP (Nomor Pokok Wajib Pajak) Rahin. ${ }^{11}$

Calon nasabah mengajukan kredit melalui bendahawan gaji pada instansi/perusahaan tempat bekerja, mengisi formulir yang telah disediakan dengan menyerahkan persyaratan yang ditentukan, Pembiayaan mulai Rp 5.000.000 hingga Rp 150.000.000, Jangka waktu kredit 12 bulan, 24 bulan, dan 36 bulan. ${ }^{12}$

Jadi dari hasil penelitian di atas maka penulis dapat menyimpulkan bahwa penentuan batas minimum dan maksimum pinjmaman dari Pegadaian Amanah bertujuan untuk menentukan keuntungan dan kemungkinan kerugian dari pemberian pinjaman dan jaminan. Cara pembayaran angsuran dari nasabah produk pegadaian amanah di cabang pegadaian syariah dicicil tiap bulan, besar dan lamanya cicilan dihitung berdasarkan besarnya pinjaman, jenis kendaraan bermotor, dan kemampuan nasabah. Yang semuanya dimasukkan dalam pendekatan rumus yang telah dijelaskan sebelumnya

\section{Pembagian risiko dalam pembiayaan Amanah}

Jika terdapat kerusakan pada objek pembiayaan maka hukumnya dibagi 2, pertama jika kerusakan tersebut terjadi saat objek pembiayaan berada di pihak penjual maka murabahah dinyatakan berakhir, kedua jika kerusakan tersebut terjadi saat objek pembiayaan berada di

\footnotetext{
${ }^{11}$ Wawancara dengan Mochtar Kadi. Amd. Ak selaku Analis dan dokumen dari kantor Cabang Pegadaian Syariah Istiqlal Manado, Tanggal 6 November 2013.

${ }^{12}$ Syamsul Anwar, Hukum Perjanjian syariah Studi tentang Teori Akad dalam Fikih Muamalat (Jakarta: PT. Raja Grafindo Persada, 2007), h. 89.
} 
tangan nasabah maka murabahah tidak dinyatakan berakhir dan tetap lanjut dengan biaya kerusakan ditanggung oleh nasabah atau asuransi yang bekerja sama. Ketiga jika dalam pembiayaan berupa kredit macet, penipuan dll, maka upaya penyelesaian masalah di produk Pegadaian Amanah di Cabang Pegadaian syariah ada masalah berupa dengan prosedur operasional standar Pegadaian Amanah tentang pengelolaan pinjaman bermasalah. ${ }^{13}$ Dalam prosedur operasional standar tersebut dijelaskan langkah-langkah penyelesaian masalah dengan 3 tahapan yaitu upaya persuasif, pemberian surat peringatan (somasi) sebanyak 3 kali dan terakhir dilakukan prosedur eksekusi marhun dan jika nasabah yang bersangkutan meninggal maka yang menjadi kewajiban untuk melanjutkan pembayaran adalah kelurga atau asuransi. ${ }^{14}$

Risiko-risiko yang mungkin terjadi dalam pembiayaan murabahah antara lain: ${ }^{15}$

1) Risiko terkait dengan barang

Pegadaian Syariah membeli barang-barang yang diminta oleh nasabahnya dan secara teoritis menanggung risiko kehilangan atau kerusakan pada barang-barang tersebut dari saat pembelian sampai diserahkan kepada nasabah. Pegadaian Syariah dengan akad murabahah, diwajibkan untuk menyerahkan barang kepada nasbah dalam kondisi baik.

2) Risiko terkait dengan nasabah

Janji nasabah untuk membeli barang yang dipesan dalam suatu transaksi murabahah, tidaklah mengikat. Nasabah berhak menolak membeli barang ketika Pegadaian Syariah menawari mereka untuk berjualan.

3) Risiko terkait dengan pembayaran

Risiko tidak terbayar penuh atau sebagian dari pembiayaan, seperti yang dijadwalkan dalam akad, ada dalam pembiayaan murabahah.

Menurut jumhur ulama bahwa akad murabahah tidak berakhir, jika salah seorang yang berakad meninggal dunia, sedangkan pembayarannya belum lunas; maka ahli warisnya, yang harus membayar lunas.

\footnotetext{
${ }^{13}$ Wawancara dengan Mochtar Kadi. Amd. Ak selaku Analis dan dokumen dari kantor Cabang Pegadaian Syariah Istiqlal Manado, Tanggal 6 November 2013.

${ }^{14}$ Wawancara dengan Mochtar Kadi. Amd. Ak selaku Analis dan dokumen dari kantor Cabang Pegadaian Syariah Istiqlal Manado, Tanggal 6 November 2013.

${ }^{15}$ Muhammad, Sistem dan Prosedur Operasional Bank Islam (Yogyakarta: UII Press, 2000), h. 127
} 
Jadi dari penjelasan di atas maka penulis dapat menyimpulkan akan terjadi risiko dalam Pegadaian Amanah apabila kerusakan tersebut terjadi saat objek pembiayaan berada di tangan nasabah, jika pembiayaan terjadi bebrapa masalah berupa kredit macet, penipuan. Sedangkan dalam upaya penyelesaian masalah di produk Pegadaian Amanah di Cabang Pegadaian syariah ada masalah berupa dengan prosedur operasional standar Pegadaian Amanah tentang pengelolaan pinjaman bermasalah. Dalam prosedur operasional standar tersebut dijelaskan langkah-langkah penyelesaian masalah dengan 3 tahapan yaitu upaya persuasif, pemberian surat peringatan (somasi) sebanyak 3 kali dan terakhir dilakukan prosedur eksekusi marhun.dan jika yang bersangkutan meninggal dunia yang berkawajiban membayar adalah keluarga atau asuransi.

\section{Minat karyawan dalam produk Amanah}

Ada beberapa faktor yang menarik minat para karyawan yang menjadi nasabah produk Amanah ini, diantaranya adalah persyaratan sederhana, prosedur mudah, akad secara tertulis, pembiayaan/hutang dengan jaminan barang yang sudah dibeli, tidak dipungut bunga, keuntungan/margin dan isi perjanjian ditentukan oleh kedua belah pihak serta pembiayaan tidak mengandung gharar dan juga berlandaskan hukum ekonomi Islam. Dan yang paling utama adalah karena mereka ingin beraktifitas ekonomi yang sesuai dengan hukum-hukum Islam.

\section{B. Pandangan Ekonomi Islam dalam Produk Amanah}

Produk Amanah adalah pemberian pinjaman guna kepemilikan kendaraan bermotor kepada para pegawai tetap pada instansi/perusahaan tertentu atas dasar besarnya penghasilan (gaji) dalam waktu tertentu dengan pengembalian dilakukan secara angsuran. Adapun maksud dan tujuannya adalah melayani kebutuhan masyarakat, khusus untuk pegawai tetap atas dasar kepemilikan kendaraan bermotor. Berdirinya satu pegadaian amanah ini tentu berdasarkan satu kebijakan operasional yang tentunya berdasarkan hukum Islam, seperti yang dijelaskan dalam landasan syariah yang bersumber dari Al-Quran dan Hadis serta pendapat para ulama yang menjadi pegangan umat Islam dalam kehidupan di berbagai bidang termasuk dibidang ekonomi. Kebijakan operasional ini sendiri berasal dari beberapa potongan ayat Al-Quran sperti dalam QS. Al-baqarah (2): 280, QS. An-Nissa (4): 29, QS. Al-maidah (5): 1 dan juga hadis Rasulullah dan pendapat ulama yang semuanya secara umum menjelaskan tentang dasar-dasar hukum Ekonomi 
Islam dalam berdagang, utang-piutang dan Pegadaian. Itulah yang menjadi pandangan ekonomi Islam yang juga menjadi landasan operasional di Pegadaian syariah ${ }^{16}$

Ilmu ekonomi Islam merupakan ilmu pengetahuan sosial yang mempelajari masalahmasalah ekonomi rakyat yang diilhami oleh nilai-nilai Islam. Dengan ini tidaklah hendak dikatakan bahwa kaum muslimin dicegah untuk mempelajari masalah-masalah ekonomi yang non-muslim. Sebaliknya, mereka yang diilhami oleh nilai-nilai Islam dperintahkan syariat untuk mempelajari masalah minoritas non-muslim dalam sebuah negara Islam khususnya, dan mengenai kemanusiaan pada umumnya. ${ }^{17}$

Seperti dalam firman Allah dalam Al-Quran:

a. Q.S. An-nisa (4): 29



Terjemahnya:

Hai orang-orang yang beriman, janganlah kamu saling memakan harta sesamamu dengan jalan yang batil, kecuali dengan jalan perniagaan yang Berlaku dengan suka sama-suka di antara kamu. dan janganlah kamu membunuh dirimu. Sesungguhnya Allah adalah Maha Penyayang kepadamu. ${ }^{18}$

b. Q.S. Al-Baqarah (2): 275

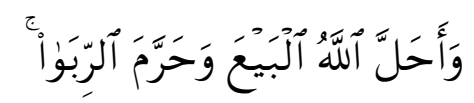

Terjemahnya: ...Padahal Allah telah menghalalkan jual beli dan mengharamkan riba... ${ }^{19}$

\footnotetext{
${ }^{16}$ Wawancara dengan Wagiman. SE selaku pimpinan cabang dan dokumen dari kantor Cabang Pegadaian Syariah Istiqlal Manado, Tanggal 6 November 2013.

${ }^{17}$ Manan, M.A, Ekonomi Islam teori dan Praktek: dasar-dasar Ekonomi Islam (Jakarta: PT. Intermasa, 1992), h. 19

${ }^{18}$ Departeman Agama RI, Al-Qur'an dan Terjemahannya (Semarang: CV. Asy-Syifa', 1999), h. 159.

${ }^{19}$ Ibid, h. 87.
} 
c. Q.S. Al-Maidah (5): 1

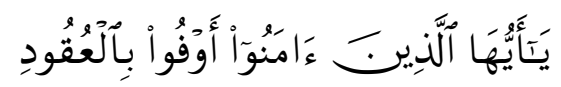

Terjemahnya: Hai orang-orang yang beriman, penuhilah aqad-aqad itu. ${ }^{20}$

d. Q.S. Al-Baqarah (2): 280

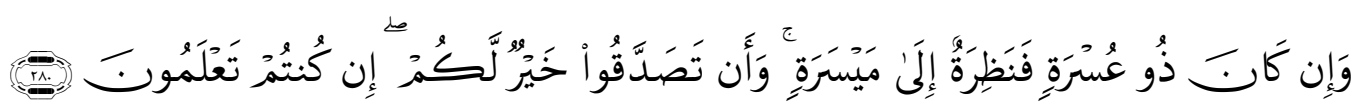

Terjemahnya:

Dan jika (orang yang berhutang itu) dalam kesukaran, Maka berilah tangguh sampai Dia berkelapangan. dan menyedekahkan (sebagian atau semua utang) itu, lebih baik bagimu, jika kamu mengetahui. ${ }^{21}$

Dari penjelasan di atas penulis dapat menyimpulkan bahwa produk Amanah pembiayaan kepemilikan kendaraan bermotor di Pegadaian sudah sesuai dengan konsep ekonomi Islam. Karena produk Amanah telah memberikan salah satu solusi penting dalam menyelesaikan masalah ekonomi rakyat berdasarkan nilai-nilai Islam yang tentunya lebih memberi kenyamanan bagi setiap nasabah yang ingin beraktifitas ekonomi yang sesuai dengan syariat Islam. Tetapi juga tetap terbuka bagi nasabah non-muslim karena pada dasarnya syariat ekonomi Islam juga mempelajari masalah minoritas non-muslim dalam sebuah negara Islam dan mengenai kemanusiaan pada umumnya.

\section{KESIMPULAN}

Berdasarkan hasil penelitian dan pembahasan yang t*elah diuraikan di atas, maka penulis dapat menarik beberapa kesimpulan yaitu:

1. Ada beberapa faktor yang menarik minat para karyawan yang menjadi nasabah produk Amanah ini, diantaranya adalah persyaratan sederhana, prosedur mudah, akad secara tertulis, pembiayaan/hutang dengan jaminan barang yang sudah dibeli, tidak dipungut bunga, keuntungan/margin dan isi perjanjian ditentukan oleh kedua belah pihak serta pembiayaan tidak mengandung gharar dan juga berlandaskan hukum

\footnotetext{
${ }^{20} \mathrm{Ibid}$, h. 206.
}

${ }^{21}$ Ibid, h. 89. 
ekonomi Islam. Dan yang paling utama adalah karena mereka ingin beraktifitas ekonomi yang sesuai dengan hukum-hukum Islam.

2. Upaya yang telah dilakukan oleh Cabang Pegadaian Syariah Istiqlal Manado sehingga pelaksanaan pembiayaan Produk Amanah dengan akad sesuai dengan kaidah-kaidah Hukum Islam:

a. Persyaratan dan prosedur pemberian pinjaman atau pembiayaan telah ditentukan oleh Pegadaian syariah berdasarkan kaidah-kaidah Hukum Islam: persyaratan sederhana, prosedur mudah, akad secara tertulis, pembiayaan/hutang dengan jaminan barang yang sudah dibeli, tidak dipungut bunga, keuntungan/margin dan isi perjanjian ditentukan oleh kedua belah pihak serta pembiayaan tidak mengandung gharar.

b. Pegadaian Syariah Istiqlal melakukan analisis pembiyaan secara obyektif yang meliputi aspek-aspek: karakter (character), kemampuan (capacity), kondisi (condition) dan kepercayaan.

3. Pembiayaan kepemilikan kendaraan bermotor bagi karyawan yang ada di kantor Cabang Pegadaian syariah Kota Manado sudah sesuai dengan hukum ekonomi Islam karena karena alasan sebagai berikut:

a. Mayoritas nasabah memilih Produk Amanah di Pegadaian karena ingin beraktifitas di bidang ekonomi sesuai dengan syariat Islam.

b. Pelaksanaan akad/perjanjian dalam Produk Amanah telah sesuai syarat dan rukunnya menurut hukum Ekonomi Islam, baik yang menyangkut al-'akid (para pihak), al-ma'kud 'alaih (obyek perjanjian) maupun sighat (ijab dan kabul).

\section{DAFTAR PUSTAKA}

Al-`Assal, Ahmad Muhammad dan Karim, Fathi Ahmad Abdul, Sistem Ekonomi Islam, Prinsipprinsip dan Tujuan-tujuannya, Surabaya: PT Bina Ilmu, 1980

Arifin, Zainal, Memahami Bank Syariah, Jakarta: Alvabet, 2000

Atmaja, Karnaen Perwata, Apa Dan Bagaimana Bank Islam, Yogyakarta: Dana Bakti Prima, 1992

Anwar, Syamsul, Hukum Perjanjian syariah Studi tentang Teori Akad dalam Fikih Muamalat, Jakarta: PT. Raja Grafindo Persada, 2007 
Antonio, Muhammad Syafi'i, Bank Syariah dari Teori ke Praktek Cet. I; Jakarta : Gema Insani Press, 2001

----------, Bank Syariah Suatu Pengenalan Umum, Cet. I; Jakarta: BI kerjasama dengan Tazkia Institute, 1999

Basyir, Ahmad Azhar, Asas-asas Hukum Muamalat Hukum Perdata Islam, Ed. Revisi, Yogyakarta: UII Press, 2000

Karim, Adi Warman, Bank Islam Analisis Fiqih dan Keuangan, Jakarta: PT. Raja Grafindo Persada, 2006

Kansil, Christine S.T., Kitab Undang-Undang Hukum Perusahaan, Jakarta: PT. Pradnya Paramita, 2001

Departemen Pendidikan dan kebudayaan, Kamus Besar Bahasa Indonesia, cet. IX; Jarkarta: Balai Pustaka, 1997

Departeman Agama RI, Al-Qur'an dan Terjemahannya, Semarang: CV. Asy-Syifa', 1999

Djuwaini, Dimyaudin, Pengantar Fiqh Muamalah, Yogyakarta: Pustaka Pelajar, 2008

Dzajuli, H.A., Fiqih Siyasah-Implementasi Kemaslahatan Ummat dalam Rambu-rambu Syari'ah, Jakarta: Prenada Media, 2003

Dewi, Gemala, Aspek-aspek Hukum dalam Perbankan dan Perasuransian Syariah di Indonesia, Edisi Revisi, Jakarta: Kencana Prenada Media Group, 2006

Harahap, M. Yahya, Segi-Segi Hukum Perjanjian, cetak.II; Bandung: Alumni, 1986

Hadi, Abu Sura'i Abdul, Bunga Bank Dalam Islam, alih bahasa M. Thalib, Surabaya: al-Ikhlas, 1993

Ismail, Perbankan Syariah, Jakarta: Kencana, 2011

Kasmir. Bank dan Lembaga Keuangan Lainnya. Jakarta: PT Raja Grafindo, 2004

Mustaghfirin, Rekonstruksi Sistem Hukum Perbankan di Indonesia, Kajian dari Aspek Filosofis, Sosiologis dan Budaya, Semarang, UNISSULA Press, 2006 
Manan, M.A, Ekonomi Islam teori dan Praktek (dasar-dasar Ekonomi Islam), Ed. 1; Jakarta: PT. Intermasa, 1992

Muhammad, System dan Prosedur Operasional bank Islam, Yogyakarta: UII Press, 2000

Mertokusumo, Sudikno, Mengenal Hukum Suatu Pengantar, Yogyakarta: Liberty, 1991

Sudarsono, Heri, Bank dan Lembaga Keuangan Syariah Depenelitian dan Ilustrasi, Yogyakarta: Ekonisia, 2003

Syafei, Rahmat, Fiqh Muamalah untuk UIN, STAIN, PTAIS dan Umum, Bandung: Pustaka Setia, 2006

Sjahdeni, Sutan Remi, Perbankan Islam dan Kedudukannya dalam Tata Hukum Perbankan Indonesia, Jakarta: Pustaka Utama Graffiti, 2005

Sabiq Sayyid, Fikih Sunnah, Terjemah, Jilid 12, Terjemahan Kamaluddin A.M, Bandung: PT. Al-Ma'arif, 1988

Sofwan, Sri Soedewi Masjchuoen, Hukum Perdata Hukum Perutangan, Bagian B, Yogyakarta: Liberty, 1975

Brosur Pegadaian Syariah Istiqlal Manado tentang Pegadaian Amanah

Pedoman Operasional PEGADAIAN AMANAH untuk Pembiayaan kendaraan Bermotor, Divisi Litbang dan Pemasaran Perum Pegadaian

Undang-undang Nomor 42 tahun 1999 tentang Fidusia Pasal 1 point 1

Undang-undang Nomor 42 tahun 1999 tentang Fidusia Pasal 1 point 2 